\title{
Comparing two assays for clinical genomic profiling: the devil is in the data [Letter of clarification]
}

\author{
This article was published in the following Dove Press journal: \\ OncoTargets and Therapy \\ 18 September 2015 \\ Number of times this article has been viewed
}

\author{
Glen J Weiss \\ Vivek Khemka \\ Cancer Treatment Centers of America, \\ Western Regional Medical Center, \\ Goodyear, AZ, USA
}

\section{Disclosure}

GJW is a clinical oncology advisor to Viomics and a scientific and medical advisor to Paradigm. All authors had control of the data and information submitted for the reply to the letter to the editor. The authors report no other conflicts of interest in this communication.

\section{Reference}

1. Squillace RM, Frampton GM, Stephens PJ, Ross JS, Miller VA. Comparing two assays for clinical genomic profiling: the devil is in the data. Onco Targets Ther. 2015;8:2237-2242.

\section{Dear editor}

It has come to our attention that the second and fourth paragraph of our Authors' reply ${ }^{1}$ may be misconstrued as an endorsement of the Paradigm Cancer Diagnostics (PCDx) test by Cancer Treatment Centers of America, Western Regional Medical Center, Goodyear, AZ, USA. This was not our intention. We stand by the interpretation of the results of the original manuscript and the remainder of the content of the Authors' reply. We welcome a more robust clinical comparison of these two platforms, as well as any other platform that may improve the clinical decision-making and outcomes for patients with advanced cancer.
\end{abstract}

Correspondence: Glen J Weiss

Cancer Treatment Centers of America,

14200 West Celebrate Life Way,

Goodyear, AZ 85338, USA

Tel +l 6232073000

Fax +l 6232073003

Email glen.weiss@ctca-hope.com

\author{
rets. $2015 ; 8: 2237-2242$.
}

